\title{
The Effect of Using Guided Questions Technique on Students' Ability in Writing Personal Letter at MAN 2 Kuantan Singingi
}

\author{
Masitha Rahma \\ Faculty of Education and Teacher Training, \\ State Islamic University of Sultan Syarif Kasim Riau, \\ Pekanbaru, Riau, Indonesia \\ masitharahma1999@,gmail.com
}

\begin{abstract}
The objectives of this research were to know the average score of students' ability in writing personal letter before and after being taught by using Guided Questions Technique and to examine whether there is significant effect of Guided Questions Technique on students' ability in writing personal letter. This research was a preexperimental design in the form of one group pre-test and post-test design on quantitative approach. The population of the research was the students of the eleventh grade at MAN 2 Kuantan Singingi consisting of 4 classes (XI IPA 1, XI IPA 2, XI IPS 1, and XI IPS 2). By having cluster sampling, it has been selected 20 students from XI IPS 1 out of 105 students on population. To collect the data, the researcher used writing test to know the students' ability in writing personal letter. The data were analyzed by non-parametric test since the assumption of normally distributed data was not markedly violated. However, the data were interpreted by using Wilcoxon on the SPSS version 23.0 program. The result of the data analyzed showed that the mean score of the students after being taught by using Guided Questions Technique (82.81) was higher than before being taught by using Guided Questions Technique (68.59). In conclusion, the use Guided Questions Technique shows a significant effect on the students' ability in writing personal letter at MAN 2 Kuantan Singingi.
\end{abstract}

Keywords: Guided Questions Technique, Writing, Ability.

\section{INTRODUCTION}

As one of the four skills, writing plays an important role in mastering language, especially in the term of English. Mentioned by Hughey (1983), writing is a means of increasing other language competences. While gathering the information about what to write, a writer should do reading, observing, talking to others, synthesizing and evaluating the data. Saville and Troike (2006) also said that to know the ability or knowledge of the learners, writing is a common medium for testing it. From those explanations, it can be concluded that writing is very crucial.

The importance of writing's skill is also indicated in curriculum education of Indonesia. It is based on Curriculum 2013 (K13) for state of 
senior high school that provides writing as one of the mastered skills in English subject. From that statement, the teachers' role is needed in order to help students during writing. Harmer (2004) mentioned that the teachers need to rethink the way they react to students' work in order for a process writing approach to work well.

One of the schools that uses Curriculum 2013 is State Islamic Senior High School 2 Kuantan Singingi (MAN 2 KUANSING), Kuantan Singingi Regency, in Riau Province. In this school, English is taught twice a week with a duration of 45 minutes for one meeting. The standard of the passing grade in English subject is 75 points.

However, the researcher found some writing problems of the students based on the preliminary study of the researcher after interviewing the two English teachers who teach at the second year students of MAN 2 Kuantan Singingi which consists of four classes (XI IPA 1, XI IPA 2, XI IPS 1, and XI IPS 2). The problems are some students were still difficult to write what ideas should be written first. They wasted their time to think while they have limited time. Although they have written the first sentence, they continue being confused what should be written for the next sentences. In conclusion, the problems that still faced by some students were indicated in some symptoms as follows:

1. Some students were still confused when they are assigned for writing,

2. Some students were difficult to start their writing process,

3. Some students were difficult to organize their ideas,
4. Some students took a longtime in thinking their ideas,

5. Some students have limited time in writing in the classroom.

Those problems can be normally happened because writing is not an easy skill. It has been explained by Hughey, et al. (1983), he stated that writing is more complicated in its production. Reading, vocabulary, and grammar skills are needed in a writing activity.

From the statements above, the teachers' role is needed in order to help students during writing. Harmer (2004) mentioned that the teachers need to rethink the way they react to students' work in order for a process writing approach to work well. From this situation, the teacher can use Guided Questions Technique. Warochmah (2017, p.58) said that, "Guided Question is one of techniques that can make the students easier to write their ideas into a written paragraph or essay. It is a technique in which the teacher gives a topic and some questions to the students, than they answer those questions based on the topic given". From that statement, the teacher gives a topic to the students and provides them some questions related to the topic. The next steps are the students answer the questions first and try to develop it into paragraphs. So, this technique can guide the students to write in better organization. Also, they do not need to take a long time to think what they should write in their first paragraph. In addition, the finding and the discussion of this research are contributed to give the valuable input to all teachers of English, especially to the English teachers at MAN 2 Kuantan Singingi as an attempt to 
improve the students' ability in writing.

The researcher specifies the problem discussed in the following formulated questions as follows:

a. What is the average score of the students' ability in writing personal letter before being taught by using Guided Questions Technique?

b. What is the average score of the students' ability in writing personal letter after being taught by using Guided Questions Technique?

c. Is there any significant effect of the students' ability in writing personal letter before and after being taught by using Guided Questions Technique?

\section{LITERATURE REVIEW}

\section{a. Writing}

According to Langan (2011), the first idea that should be built is that writing is a skill, so it is not a natural gift. He said that writing's skill is like skill in driving, typing, cooking and other skills which can be learned. In addition, Raimes (1983) assumed that people have to communicate with each other in writing. From writing, they are learning to how to communicate when the other person is not right there in front of them and without listening to the words and looking at gestures and facial expressions.

Another opinion comes from Brown (2004), he states that writing is a crucial condition for getting a job in many aspects of life. Writing is also an indispensable skill which is needed in a global literate community. From the stated definitions, it can be concluded that writing is an important skill which is used to convey information in written form, to get a job and to involve in global literate community.

In order to find out how good writing is produced, the researcher used a rubric which was taken from the Teacher's English Book grade eleven provided by Curriculum 2013. Writing is rated on four aspects: content, organization, language use, and vocabulary.

\section{b. Personal Letter}

The discussion about personal letter, the researcher takes all of the explanations from the English book of the students entitles Bahasa Inggris SMA/MA/SMK/MAK Kelas XI 2017.

1) Definition of Personal Letter

Personal letters are letters that are written to people we know such as friends, parents, siblings, and cousins.

2) Purpose of Letter

Letters are not only written to inform but also to strengthen the bond between two people writing to each other.

3) Linguistic Features

Sentence structure contains of accuracy of grammar is important, complete sentences are expected, slang can be used, use the contractions such as "I'll", "I'm", "we'll", use personal pronouns such as "I", "we", "you", and use active voice.

Style consists of language use may be personal like first and second person pronouns, be warm, use the person's name you are writing to, vary sentence length, write in a natural, conversational style, and let your personality shine through in your writing.

4) Structure of Personal Letter

The structures of personal letter are date, address, salutation and name, introduction, body, 
closure, complimentary close, signature, and postscript P.s.

\section{c. Guided Questions Technique}

Langan (2011) stated that questioning is one of five techniques in prewriting stage that will help writers think about and develop a topic and get words on paper. In questioning, writers generate ideas and details by asking questions about the subject. Such questions include why, when, where, who, and how. Asking questions can be an effective way of thinking about a topic from a number of different angles. The questions can really help writers generate details about a topic.

According to Taylor (2009), here are the steps in doing Guided Questions Technique:

1) Choose a topic because it interests the writer.

2) Ask questions of the topic.

3) Propose to writer's self a few likely answers to the raised question by the topic and write them down in no more than a sentence or two

4) Develop this answer into a paragraph which, so far as the writer can, lists the reasons for choosing the answer you did or some of the facts and ideas that you think might support it.

5) Regard this paragraph as no more than a hypothesis about, a proposal for, or a forecast of, eventual answer.

Another step for doing guided questions came from Cooper and Axelrod (1985, p.475) in Warochmah (2017). They said that there are several steps in using guided question for invention. They are:

1) Think about the subject. ("Subject" means any event, person, problem, project, idea, or issue. In other words, anything you might write about).

2) Start with the first question and move right through the list. Try to answer each question at least briefly with a word or phrase.

3) Write the responses quickly, without much planning.

\section{d. Teaching Writing Using Guided Questions Technique}

Based on the steps that explained by the experts above, the writer in this research used several steps below by mixing the steps from the experts in using guided question technique in teaching writing:

1) The teacher shares the topics related to the personal letter. The topic is about self-activity and people around.

2) The teacher provides the questions to be answered by the students related to the topic.

3) The students answer the questions quickly.

4) The students develop their quick answers into paragraphs by analyzing and developing the answers.

\section{e. Hypothesis}

- Ho (null hypothesis)

There is no a significant effect on students' ability in writing personal letter taught by using Guided Questions Technique.

- Ha (alternative hypothesis) There is a significant effect on students' ability in writing personal letter taught by using Guided Questions Technique. 


\section{METHOD}

This research employed a preexperimental design in the form of onegroup pre-test post-test design with a quantitative approach. Ary (2010) stated that this design is used because it provides little or no control of extraneous variables. Also, Campbell (1963) claimed that the experiment which is done between the pre-test and the post-test may cause the difference results between the two tests. In addition, Ary (2010) explained that there will be three steps of the one-group pretestposttest design: (1) administering a pretest; (2) applying the experimental treatment $\mathrm{X}$; and (3) administering the posttest.

Due to the design of this research is for one group pretest-posttest, so the data was analyzed with Repeated Measured or Related Samples. In this research, the researcher used Wilcoxon test due to the data of this research was not normal. It was according to Leech (2005), he mentioned that Wilcoxon test is used if the dependent variables clearly ordinal or parametric assumptions markedly violated. To find out whether or not the significant effect between using and without guided questions technique on students' ability in writing, the data was calculated by using SPSS application 23.0 version.

\section{FINDINGS AND DISCUSSION}

From the table 4.1. shows that the total number of students was 20 students. The mean score of the students' pre-test was 68.59 and the mean score of the students' post-test was 82.81, the standard deviation of the students' pretest was 56.88 and the standard deviation of the students' post-test was 44.77. The minimum score of students' pre-test was 56.25 and the minimum score of students' post-test was 71.88 . Meanwhile, the maximum score of students' pre-test was 78.13 and the maximum score of students' post-test was 90.63 .

Table 4.1.

The Descriptive Statistic of Pre-Test and Post-Test Class

\begin{tabular}{ccccccc}
\hline & N & Range & Minimum & Maximum & Mean & Std. Deviation \\
\hline Pre-Test & 20 & 21,88 & 56,25 & 78,13 & 68,59 & 56,88 \\
Post-Test & 20 & 18,75 & 71,88 & 90,63 & 82,81 & 44,77 \\
Valid N (listwise) & 20 & & & & & \\
\hline
\end{tabular}

Based on the output SPSS on table 4.2., Wilcoxon-Test shows the asymp significant value. Ho: Variance Population identical and Ha: Variance Population not identical. If Probabilities $>0.05$, Ho is accepted, If Probabilities < 0.05 , Ha is accepted.

Based on the output SPSS above, $\mathrm{Ha}$ is accepted because $0.000<0.05$. It means that the variance of the population is not identical. From the output above, it also can be seen that the sig (2-tailed) value is 0.000 . It can be stated that $0.000<0.05$. It means that null hypothesis (Ho) is rejected, while the alternative hypothesis (Ha) is accepted. It can be concluded $\mathrm{Ha}$ is accepted and Ho is rejected. 
Masitha Rahma- The Effect of Using Guided Questions Technique on ....

Table 4.2.

Significant Effect between Pre-Test and Post-Test Score

\begin{tabular}{lr}
\hline \multicolumn{2}{c}{ Test Statistics $^{\mathrm{a}}$} \\
& \multicolumn{2}{c}{ Post Test - Pre Test } \\
\hline $\mathrm{Z}$ & $-3.830^{\mathrm{b}}$ \\
Asymp. Sig. (2-tailed) & .000 \\
a. Wilcoxon Signed Ranks Test & \\
b. Based on negative ranks. \\
\hline
\end{tabular}

In conclusion, teaching writing after using Guided Questions Technique at the eleventh grade of at MAN 2 Kuantan Singingi is better than before using Guided Questions Technique. Thus, there is a significant effect of using Guided Questions Technique on Students' Ability in Writing Personal Letter at MAN 2 Kuantan Singingi.

\section{CONCLUSION}

Referring to the finding, finally the researcher concludes that there is a significant effect of using Guided Questions Technique on Students' ability in writing personal letter at MAN 2 Kuantan Singingi.

\section{REFERENCES}

Ary, Donald., Lucy Cheser Jacobs, Asghar Razavieh, Christine K. Sorensen. 2010. Introduction to Research in Education, 8th Edition. Belmont: Wadsworth Publishing.

Brown, H. Douglas. (2004). LANGUAGE ASSESSMENT: Principles and Classroom
Practices. New York: Pearson Education.

Campbell, Donald T. \& Stanley, Julian C. (1963). Experimental and Quasi-Experimental Designs for Research. Chicago: Houghton Mifflin Company.

Harmer, Jeremy. (2004). How to Teach Writing. England: Longman.

Hughey, Jane B., et al. (1983). Teaching ESL Composition: Principles and Techniques. Massachusetts : Newbury House Publishers, Inc.

Kementerian Pendidikan dan Kebudayaan Republik Indonesia. (2017). Bahasa Inggris: SMA/MA/SMK/MAK KELAS XI.

Kementerian Pendidikan dan Kebudayaan Republik Indonesia. (2017). Buku Guru Bahasa Inggris: SMA/MA/SMK/MAK KELAS XI.

Langan, John. (2011). College Writing Skills with Readings. New York: McGraw-Hill.

Raimes, Ann. (1983). Techniques in Teaching Writing. New York: Oxford University Press. 
Masitha Rahma- The Effect of Using Guided Questions Technique on ....

Saville, Muriel and Troike. (2006). Introducing Second Language Acquisition. New York: Cambridge University Press.

Taylor, Gordon. (2009). A Student's Writing Guide: How to Plan and Write Successful Essays. Cambridge: Cambridge University Press.

Warochmah, Dwi., \& Qamariah, Zaitun. (2017). Writing Fluency through the Use of Guided Questions. International Conference on Language Teaching (INACELT). Proceedings of The 1 st INACELT, 57-68. 